\title{
Idiopathic bronchiectasis
}

INSERM

\section{Source}

INSERM. (1999). Orphanet: an online rare disease and orphan drug data base. Idiopathic bronchiectasis. ORPHA:60033

\#160;(IB) is a progressive lung disease characterized by chronic dilation of the bronchi and destruction of the bronchial walls in the absence of any underlying cause (such as post infectious disease, aspiration, immunodeficiency, cong enital abnormalities and ciliary anomalies). 